\title{
Demographic Differences in Organizational Commitment among Catholic Religious Men and Women Working in Rural Areas: A Case of Lodwar Diocese in Turkana County, Kenya
}

\author{
Wambua Pius Muasa ${ }^{1}$, Sahaya. G. Selvam $(\mathrm{PhD})^{2}$, Elijah Macharia Ndung'u $(\mathrm{PhD})^{3}$ \\ ${ }^{l}$ Department of Counselling Psychology, Catholic University of Eastern Africa \\ ${ }^{2}$ Institute of Youth Studies, Tangaza University College \\ ${ }^{3}$ Department of Counselling Psychology, Catholic University of Eastern Africa
}

\begin{abstract}
This study sought to examine organizational commitment among Catholic religious men and women. This was as result of the fact that organizational commitment could affect other psychological dispositions of these men and women which could affect their overall functioning in ministry. The study was guided by two theories: Maslach Burnout Model by Maslach and Jackson and Job Demands-Resources Model by Bakker and his colleagues. The study adopted descriptive research design. Using census sampling, a sample size of 131 participants was included in the study which comprised the whole population of the study. The data was collected using a standardized questionnaire. Pretesting of standardized instruments was carried out before the actual data collection to ensure its reliability and validity. The data was analyzed using descriptive statistics using SPSS Version 32. The study found that the level of organization commitment was high (mean=21.7608) among respondents. Specifically, the subscale of affective commitment had the highest score (mean=24.7405) followed by normative commitment $($ mean=22.9542) and continuance commitment (mean=17.5878).
\end{abstract}

\section{INTRODUCTION}

A ccording Meyer and Allen (1984), organizational commitment has three dimensions: affective, continuance and moral. Active commitment is the first dimension of organizational commitment. This is a type of engagement in which the organization's participants have a voluntary psychological link with the organization (Lambert et al., 2008). Those who have this form of commitment identify themselves with the congregation and they work towards making the organization realize its goals and mission (Mowday, 1998). Members form commitment with the organization because they perceive positive treatment and that allows them to have sense of belonging with the organization. The person with affective commitment is likely to suffer less burnout compared to those who operate from continuance and moral commitments.

Continuance commitment is the second dimension of organizational commitment. It occurs when the employees have invested widely in the organization in terms of time, contribution to the organization, level of income, relationship with the colleagues. This type of commitment continues because if the person leaves the organization is going to incur more loss than benefits (Hogan, Lembert, \& Griffin, 2013). The members have no other option other than to remain in the organization because the cost of leaving will be very high compared to remaining in the organization. This type of commitment in the organization is compared to calculative commitment because an individual has to consider the benefits and cost of remaining in the organization compared to losses and consequences of leaving the institution (Lambert et al., 2008).

In the context of congregational commitment, Catholic religious men and women may remain in the congregation based on the benefits and privileges they gain when inside compared to when they are outside. For instance, there are many benefits they may enjoy in religious life including medical cover, travels, ministry opportunities, personal and professional development, community life, prayer life, and respect by the society among others. If a member leaves the congregation, may not enjoy some of these privileges. The member may find it difficulty securing a job in the secular world and especially if they had done courses related to Church such as theology, philosophy, catechetic, pastoral counselling among others. The members may have limited opportunities of travelling as before due to financial implications. It may be even more challenging to consider another way of life such as married or single vocation when already they have advanced in age. Based on these realities, a member of congregation may chose to remain in the congregation with fear of losing these benefits.

Moral commitment is the third dimension of organizational commitment. It is the bond the individual forms with the organization after spending a long time with the organization (Penley\& Gould, 1998). According to Allen and Meyer (1990), Members are expected to make a contribution to the organization as way of way of expressing their gratitude. Members of the organization feel that they have responsibility of working towards helping the organization to realize its 
vision, mission and goals (Wiener, 1982). The members operating on this form of organizational commitment does not act out of free will for the best interest of the organization, but because they have a compelled obligation to give back to the organization (Jaros et al., 1993; Meyer \&Herscovitch, 2001).

In the context of religious life, Catholic religious men and women may demonstrate this form of commitment in giving back to the congregation based on how much resources the congregation has invested in them. For instance, since the initial formation, the congregation has taken the responsibility of taking care of all the needs of the members including, physical, emotional, spiritual, and intellectual among others. A member may feel that the congregation has invested a lot on them and leaving the congregation would be morally wrong. During perpetual profession, members of the congregation profess their vows in public promising to the leadership of the Church and Christians as witness that they going to consecrate their entire life in the Church for the service of humanity. When a member quits religious life may not be accepted by the society and may be perceived to be cursed and therefore, some members of the congregation may chose to remain in the congregation despite of having a desire to leave. The study aimed at establishing the role of demographic differences in organizational commitment among Catholic religious men and women working in rural areas.

\section{METHODS}

\section{Research Design}

According to Creswell and Creswell (2017), research designs are of inquiry in qualitative, quantitative, and mixed methods approaches which offer specific focus forms for techniques in a research design. The study adopted a descriptive design. Descriptive design is a method of collecting information by interviewing or administering a questionnaire to a sample of individuals (Orodho, 2003). It can be used when collecting information about people's attitudes, opinions, habits or any of the variety of education or social issues (Orodho \& Kombo, 2002). Descriptive design was appropriate for this study because, it described the role of demographic differences of age, gender, level of education, country of origin and vocation identity on organizational commitment among the Catholic religious men and women working in rural areas.

\section{Study Area}

This study was conducted in Lodwar Diocese Kenya. A Diocese in the context of Catholic Church is a group of parishes that are governed by a Bishop. Basically, a Diocese is divided into parishes that are each overseen by a priest. Lodwar Diocese is situated in the North-Western area of Kenya, west of Lake Turkana. In 1968 the Diocese was established as prefecture of Lodwar from the diocese of Eldoret. In the year 1978, it was promoted to become Diocese of Lodwar. It has 30 parishes served by Catholic diocesan priests, religious priests, religious brothers and sisters. It is a remote and arid area characterized by poverty and harsh living conditions. The inhabitants are faced with many problems of getting clean water, food, health, education and conflict among communities. There are community conflicts due to lack of clean water and pressure for herds. The Catholic religious men and women work towards alleviating poverty by promoting peace among the communities, providing clean water, food, education, health services and above all spiritual nourishment. The commitment of Catholic religious men and women can be affected as a result of working under harsh conditions in Lodwar Diocese.

\section{Study Population}

The target population is the total group of individuals from which the sample might be drawn (McLeod, 2019). The target population was 131 Catholic religious men and women working in Lodwar diocese (priests, brothers and sisters) (Office Directory, 2021). Currently there are 36 Catholic priests serving in the diocese in which 27 of them are religious priests and 9 diocesan priests. There are 10 Catholic religious brothers and 85 sisters working in Lodwar diocese. Catholic religious men and women are people called to live a communal life, a life of prayer, professing the three evangelical vows of chastity, obedience and evangelical poverty. They also serve in apostolate in accordance with the different charisms of their founders. Their purpose of existence is rooted in Christ and his call. They have freely chosen to be celibate and see it as fundamental aspect of their commitment to others and God. They are not celibate out of necessity, misfortune, or coercion. Rather they have made an intentional commitment to a particular way of life that involves non-marriage. They profess the vow of poverty which means giving oneself, without reservation, to the cause of the reign of God, even if it means leaving one's family and renouncing the opportunity to marry and have a family. Finally, they profess the vow of obedience which is a commitment to the fundamental Christian principle that at the end of the day, all truth is communal.

\section{Sample Size and Sampling Procedure}

The study employed census sampling. Using census, the study utilized a sample size of 131 which included the whole population under the study. It is a technique utilized by researchers with an intention of collecting data on the entire eligible element within a given population. It was suitable for this study because the population was small and therefore, the whole population was included as part of the sample size (See Table 1).

Table 1: Census Technique

\begin{tabular}{|c|c|c|}
\hline Type of Population & Total Population & Sample Size \\
\hline Diocesan Priests & 9 & 9 \\
\hline Religious Priests & 27 & 27 \\
\hline Religious Brothers & 10 & 10 \\
\hline Religious Sisters & 85 & 85 \\
\hline Total & 131 & 131 \\
\hline
\end{tabular}

Source: Lodwar Catholic Diocese Office Directory (2021) 


\section{Data Collection Methods and Instruments}

The study employed a standardized questionnaire. The questionnaire contained two sections. Section A collected data on the demographic details of the participants which included age, gender, educational level, country, and vocational identity. Section B collected quantitative data on organizational commitment using the Organizational commitment scale.

\section{Organizational Commitment Scale}

The organizational commitment was measured using the modified scale of the Organizational Commitment to fit population under study. The instrument was developed by Allen and Myer in 1996. The Likert scale has three dimensions which includes affective commitment, continuance commitment and normative commitment. The instrument has 18 items in which each dimension is measured with 6 items. The participant respond to all the items using a 5- point Likert scale ranging from strongly disagree (1) to strongly agree (5). Previous studies have found high internal reliability with the organizational commitment scale. For instance, Abdullah (2011) carried out a cross-sectional study in Pakistan to evaluate the Allen and Myer organizational commitment scale and reported an alpha of 0.67 on affective commitment, 0.53 on continuance commitment and 0.67 on normative commitment. Furthermore, a study by Gbadamosi (2006) using the African samples found organizational commitment to have an internal consistency reliability of .73. The subscale of affective commitment reported alpha of .74, continuance commitment .74 and normative commitment .66. Some of the sample items of the scale include: "I would be very happy to spend the rest of my vocation life in this diocese or congregation" "Too much of my life would disrupted if I leave my diocese or congregation", "I would feel guilty if I left this diocese or congregation now". Items 3, 5, 6, and 13 are reversed and there was inverse scoring during analysis. Some items were modified to fit the population of the study. The items with career were replaced with "life", organization with "diocese or congregation", job with "ministry" and work with "serve"

\section{RESULTS}

\section{Descriptive Statistics of the Organizational Commitment}

The organizational commitment was measured using the modified scale of the Organizational Commitment developed by Allen and Myer in 1996. The scale has three dimensions which includes affective commitment, continuance commitment and normative commitment. Computations were then done on all the items in each subcategory by adding and getting the mean. The highest possible mean was 30 while the lowest possible mean was 7 . The results are presented in Table 2 .
Table 2: Descriptive Statistics of the Organizational Commitment

\begin{tabular}{|c|c|c|c|c|c|}
\hline & $\mathrm{N}$ & Minimum & Maximum & Mean & $\begin{array}{c}\text { Std. } \\
\text { Deviation }\end{array}$ \\
\hline $\begin{array}{c}\text { Affective } \\
\text { Commitment }\end{array}$ & 131 & 15.00 & 30.00 & 24.7405 & 3.38455 \\
\hline $\begin{array}{c}\text { Continuance } \\
\text { Commitment }\end{array}$ & 131 & 7.00 & 29.00 & 17.5878 & 4.73753 \\
\hline $\begin{array}{c}\text { Normative } \\
\text { Commitment }\end{array}$ & 131 & 12.00 & 30.00 & 22.9542 & 3.79648 \\
\hline Valid N & 131 & & & & \\
\hline
\end{tabular}

Table 2 shows that respondents who participated in the study had high level of organization commitment (mean=21.7608). Specifically, all the subscales of organization commitment scored a mean above average. For instance, the subscale of affective commitment had the highest score (mean=24.7405; $\mathrm{SD}=3.38455$ ) followed by the subscale of normative commitment (mean=22.9542). The subscale of continuance commitment had the least mean (mean=17.5878; $\mathrm{SD}=4.73753)$.

Majority of Catholic religious men and women scoring high in affective commitment and low in continuance and moral commitment means that they have a strong commitment to their congregations in terms of identifying with the congregation and helping it towards realizing its goals and mission. This also means that majority of the Catholic religious men and women working in Lodwar perceive they are treated well by their congregations and they have a sense of belonging. Unlike employees who are working in organizations to earn salaries, the Catholic religious men and women are ministering to God's people by dedicating their lives to the service of humanity.

\section{Age Differences in Organizational Commitment among} Respondents

The study sought to understand prevalence organizational commitment across different ages. The respondents were requested to indicate their age based on age ranges; 20-30 years, 31-40 years, 41-50 years, 51-60 years, 61-70 years and 71-80 years. Means for the two variables were computed and then compared. The results are shown in Table 3.

Table 3: Age Differences in Organizational Commitment

\begin{tabular}{|c|c|c|c|c|}
\hline \multicolumn{2}{|c|}{$\begin{array}{c}\text { Age of the } \\
\text { Respondents }\end{array}$} & $\begin{array}{c}\text { Affective } \\
\text { Commitment }\end{array}$ & $\begin{array}{c}\text { Continuance } \\
\text { Commitment }\end{array}$ & $\begin{array}{c}\text { Normative } \\
\text { Commitment }\end{array}$ \\
\hline \multirow{2}{*}{$\begin{array}{l}20-30 \\
\text { years }\end{array}$} & Mean & 25.8000 & 16.2500 & 22.7500 \\
\cline { 2 - 5 } & $\begin{array}{c}\text { Std. } \\
\text { Deviation }\end{array}$ & 2.96648 & 3.59642 & 3.64005 \\
\hline \multirow{3}{*}{$\begin{array}{c}31-40 \\
\text { years }\end{array}$} & Mean & 23.6042 & 18.1458 & 23.1042 \\
\cline { 2 - 5 } & $\mathrm{N}$ & 48 & 48 & 48 \\
\cline { 2 - 5 } & $\begin{array}{c}\text { Std. } \\
\text { Deviation }\end{array}$ & 3.71735 & 4.70848 & 3.62168 \\
\hline \multirow{2}{*}{$\begin{array}{c}41-50 \\
\text { years }\end{array}$} & Mean & 25.1778 & 18.1111 & 22.9778 \\
\cline { 2 - 5 } & $\mathrm{N}$ & 45 & 45 & 45 \\
\hline
\end{tabular}




\begin{tabular}{|c|c|c|c|c|}
\hline & $\begin{array}{c}\text { Std. } \\
\text { Deviation }\end{array}$ & 2.95642 & 4.77790 & 3.98571 \\
\hline \multirow{4}{*}{$\begin{array}{c}51-60 \\
\text { years }\end{array}$} & Mean & 25.2308 & 15.8462 & 22.8462 \\
\cline { 2 - 5 } & $\mathrm{N}$ & 13 & 13 & 13 \\
\cline { 2 - 5 } & $\begin{array}{c}\text { Std. } \\
\text { Deviation }\end{array}$ & 3.16633 & 4.87931 & 3.50823 \\
\hline \multirow{4}{*}{$\begin{array}{c}61-70 \\
\text { years }\end{array}$} & Mean & 24.0000 & 11.0000 & 18.0000 \\
\cline { 2 - 5 } & $\mathrm{N}$ & 1 & 1 & 1 \\
\cline { 2 - 5 } & $\begin{array}{c}\text { Std. } \\
\text { Deviation }\end{array}$ & &. & \\
\hline \multirow{4}{*}{$\begin{array}{c}\text { 71-80 } \\
\text { years }\end{array}$} & Mean & 26.7500 & 19.0000 & 23.5000 \\
\cline { 2 - 5 } & $\mathrm{N}$ & 4 & 4 & 4 \\
\cline { 2 - 5 } & $\begin{array}{c}\text { Std. } \\
\text { Deviation }\end{array}$ & 4.27200 & 7.87401 & 6.60808 \\
\hline \multirow{7}{*}{ Total } & Mean & 24.7405 & 17.5878 & 22.9542 \\
\cline { 2 - 5 } & $\mathrm{N}$ & 131 & 131 & 131 \\
\cline { 2 - 5 } & $\begin{array}{c}\text { Std. } \\
\text { Deviation }\end{array}$ & 3.38455 & 4.73753 & 3.79648 \\
\hline
\end{tabular}

Source: SPSS Output (2021)

Table 3 shows that respondents aged 71-80 years had highest mean of affective commitment (mean=26.7500) while respondents aged 31-40 years had lowest mean of affective commitment (mean=23.6042). With respect to continuance commitment, respondents aged 71-80 years were found to have highest mean of continuance commitment (mean=19.0000) while respondents aged 61-70 years had lowest mean of continuance commitment (mean=11.0000). Lastly that respondents aged 71-80 years had highest mean of normative commitment (mean=23.5000) while respondents aged 61-70 years had lowest mean of depersonalization (mean=18.0000).

The respondents aged 71-80 could have score high in affective commitment because they have actualized in their calling. Also they are likely to have attained a sense of integrity based on Erik Erikson's stages of psychosocial development. Those aged 31-40 scoring low in affective commitment could be attributed by still having other options in their life other than only religious life.

In support of these findings is a study byDonna (2015). The study investigated job satisfaction and its relationship to organizational and religious commitment among 263 workers at northern Caribbean university. The study found that age had a significant relationship with organization commitment. specifically, When a post hoc comparison using StudentNewman Keuls was done, respondents who were 46 years and older had a higher level of organization commitment( $\mathrm{M}=$ $4.71, \mathrm{SD}=0.43)$ as compared to their younger colleagues between the ages of 26 and $35\{\mathrm{M}-4.40, \mathrm{SD}=0.46$ ) and those less than 25 years of age $\{\mathrm{M}-4.24, \mathrm{SD}=0.65$ )

\section{Gender Differences in Organizational Commitment among Respondents}

The study sought to understand organization commitment across different genders. The respondents were requested to indicate their gender. Means for the two variables were computed and then compared. The results are shown in table 4.

Table 4: Gender Differences in Organizational Commitment

\begin{tabular}{|c|c|c|c|c|}
\hline \multicolumn{2}{|c|}{$\begin{array}{c}\text { Gender of the } \\
\text { Respondents }\end{array}$} & $\begin{array}{c}\text { Affective } \\
\text { Commitment }\end{array}$ & $\begin{array}{c}\text { Continuance } \\
\text { Commitment }\end{array}$ & $\begin{array}{c}\text { Normative } \\
\text { Commitment }\end{array}$ \\
\hline \multirow{4}{*}{ Male } & Mean & 24.0612 & 17.6122 & 23.3673 \\
\cline { 2 - 5 } & $\mathrm{N}$ & 49 & 49 & 49 \\
\cline { 2 - 5 } & $\begin{array}{c}\text { Std. } \\
\text { Deviation }\end{array}$ & 3.57892 & 4.39136 & 3.17342 \\
\hline \multirow{4}{*}{ Female } & Mean & 25.1463 & 17.5732 & 22.7073 \\
\cline { 2 - 5 } & $\mathrm{N}$ & 82 & 82 & 82 \\
\cline { 2 - 5 } & $\begin{array}{c}\text { Std. } \\
\text { Deviation }\end{array}$ & 3.21694 & 4.95917 & 4.12307 \\
\hline \multirow{4}{*}{ Total } & Mean & 24.7405 & 17.5878 & 22.9542 \\
\cline { 2 - 5 } & $\mathrm{N}$ & 131 & 131 & 131 \\
\cline { 2 - 5 } & $\begin{array}{c}\text { Std. } \\
\text { Deviation }\end{array}$ & 3.38455 & 4.73753 & 3.79648 \\
\hline
\end{tabular}

Source: SPSS Output (2021)

Table 4 shows that females experienced more affective commitment $($ mean $=25.1463)$ compared to males. However, males experienced more continuance commitment and normative commitment (mean $=$ 17.6122) and (mean=23.3673) respectively compared to females.

Catholic religious women scoring high in affective commitment than religious men can be based on differences in emotional bonding and cultural gender roles in the society. Generally women operate from their heart and thus why they are considered to be caring and empathetic towards others comparing to male counterparts. That could explain why they are scoring high in affective commitment than religious men. Also from cultural and religion perspective women are ought to be submissive unlike the men and therefore, since they are married in the Church naturally they are ought to show high levels of commitment.

These findings disagree with Donna (2015) study. The study found that there was no significant difference between females and males on organization commitment $\{\mathrm{t}=-1.84$, $=0.067$ ) when independent t-test was run. Similarly, Pala, Semin and Melele (2018) study findings on the effect of demographic characteristics and job characteristics on organizational commitment in Serbia's Central European Organization disagreed with the findings of this study. The study findings revealed that gender of employee does not affect organizational commitment,

\section{Educational level differences in Organizational Commitment among Respondents}

The study sought to understand organization commitment across different levels of education of respondents. The respondents were requested to indicate their educational level based on their achievements (certificate, diploma, bachelor's degree and master's degree). Means for the two variables 
were computed and then compared. The results are shown in Table 5.

Table 5: Educational level differences in Organizational Commitment

\begin{tabular}{|c|c|c|c|c|}
\hline \multicolumn{2}{|c|}{$\begin{array}{c}\text { Education Level of } \\
\text { Respondents }\end{array}$} & $\begin{array}{c}\text { Affective } \\
\text { Commitment }\end{array}$ & $\begin{array}{c}\text { Continuance } \\
\text { Commitment }\end{array}$ & $\begin{array}{c}\text { Normative } \\
\text { Commitment }\end{array}$ \\
\hline \multirow{4}{*}{ Certificate } & Mean & 24.0000 & 16.2800 & 21.6400 \\
\cline { 2 - 5 } & $\mathrm{N}$ & 25 & 25 & 25 \\
\cline { 2 - 5 } & $\begin{array}{c}\text { Std. } \\
\text { Deviation }\end{array}$ & 3.02765 & 4.44897 & 3.53412 \\
\hline \multirow{4}{*}{\begin{tabular}{c} 
Diploma \\
\cline { 2 - 5 } Bachelor's
\end{tabular}} & Nean & 25.2982 & 17.7544 & 24.0175 \\
\cline { 2 - 5 } & $\begin{array}{c}\text { Std. } \\
\text { Deviation }\end{array}$ & 3.09934 & 4.42913 & 3.88445 \\
\cline { 2 - 5 } & Mean & 24.8889 & 18.0000 & 22.4722 \\
\cline { 2 - 5 } & $\begin{array}{c}\text { Std. } \\
\text { Deviation }\end{array}$ & 3.82307 & 36 & 36 \\
\hline \multirow{3}{*}{$\begin{array}{c}\text { Master's } \\
\text { Degree }\end{array}$} & Mean & 23.3077 & 18.2308 & 22.1538 \\
\cline { 2 - 5 } & $\mathrm{N}$ & 13 & 13 & 13 \\
\cline { 2 - 5 } & $\begin{array}{c}\text { Std. } \\
\text { Deviation }\end{array}$ & 3.66025 & 4.98588 & 3.71587 \\
\hline \multirow{3}{*}{ Total } & Mean & 24.7405 & 17.5878 & 22.9542 \\
\cline { 2 - 5 } & $\mathrm{N}$ & 131 & 131 & 131 \\
\cline { 2 - 5 } & $\begin{array}{c}\text { Std. } \\
\text { Deviation }\end{array}$ & 3.38455 & 4.73753 & 3.79648 \\
\hline
\end{tabular}

Source: SPSS Output (2021)

Table 5 shows that respondents who had attained a diploma had highest mean of affective commitment (mean=25.2982), and normative commitment (mean=24.0175) while respondents who had attained masters degree had highest mean of continuance commitment (mean=18.2308). On the other hand, respondents who had attained a masters degree had lowest mean of affective commitment (mean=23.3077). Lastly that respondents who had attained certificate level of education had lowest mean of continuance commitment $($ mean $=16.2800)$ as well as normative commitment $($ mean $=21.6400)$.

Majority of those attained diploma having attained affective commitment could be attributed by the majority of participants who participated in the study. Those with a master's degree attaining high score in continuance commitment can attributed to the big responsibilities given to them. Based on their responsibilities and level of education, they are likely to have more privileges than the others and hence scoring high in continuance commitment. Those with certificates are likely not have big responsibilities in the congregations and also they could be young in religious life and therefore, they might not consider getting a lot in the congregation and hence scoring low in continuance commitment.

\section{Country of Origin differences in Organizational Commitment among Respondents}

The study sought to understand organization commitment across differences in respondents' country of origin. The respondents were requested to indicate whether they were Kenyans or not Kenyans. Means for the two variables were computed and then compared. The results are shown in Table 6.

Table 6: Country of Origin differences in Organizational Commitment

\begin{tabular}{|c|c|c|c|c|}
\hline \multicolumn{2}{|c|}{ Country of Origin } & $\begin{array}{c}\text { Affective } \\
\text { Commitment }\end{array}$ & $\begin{array}{c}\text { Continuance } \\
\text { Commitment }\end{array}$ & $\begin{array}{c}\text { Normative } \\
\text { Commitment }\end{array}$ \\
\hline \multirow{4}{*}{ Kenyan } & Mean & 24.8831 & 17.4675 & 23.2338 \\
\cline { 2 - 5 } & $\mathrm{N}$ & 77 & 77 & 77 \\
\cline { 2 - 5 } & $\begin{array}{c}\text { Std. } \\
\text { Deviation }\end{array}$ & 3.34811 & 4.62142 & 3.91655 \\
\hline \multirow{4}{*}{$\begin{array}{c}\text { Non- } \\
\text { Kenyan }\end{array}$} & Mean & 24.5370 & 17.7593 & 22.5556 \\
\cline { 2 - 5 } & $\mathrm{N}$ & 54 & 54 & 54 \\
\cline { 2 - 5 } & $\begin{array}{c}\text { Std. } \\
\text { Deviation }\end{array}$ & 3.45708 & 4.93710 & 3.61687 \\
\hline \multirow{4}{*}{ Total } & Mean & 24.7405 & 17.5878 & 22.9542 \\
\cline { 2 - 5 } & $\mathrm{N}$ & 131 & 131 & 131 \\
\cline { 2 - 5 } & $\begin{array}{c}\text { Std. } \\
\text { Deviation }\end{array}$ & 3.38455 & 4.73753 & 3.79648 \\
\hline
\end{tabular}

Source: SPSS Output (2021)

Table 6 shows that respondents who were Kenyans had higher mean of affective commitment (mean=24.8831) compared to respondents who were not Kenyans (mean=24.5370). Similarly, with respect to normative commitment, respondents who were Kenyans had higher mean (mean= 23.2338) compared to respondents who were not Kenyans (mean=22.5556). However with respect to continuance commitment, respondents who were not Kenyans had higher mean $($ mean $=17.7593)$ compared to respondents who were Kenyans $($ mean $=17.4675)$.

The respondents who were Kenyan scoring high in affective commitment than those who non-Kenyan can be attributed to familiarity of working in their country. Those who are coming outside could have been facing many challenges including language barrier, change of whether and could easily lead to low scores in affective commitment.

Vocational Identity differences in Organizational Commitment among Respondents

The study sought to understand organization commitment across different vocational identities. The respondents were requested to indicate their vocational identities which was classified as either religious brother, diocesan priest, religious priest or religious sister. Means for the two variables were computed and then compared. The results are shown in Table 7 .

Table 7: Vocational Identity differences in Organizational Commitment

\begin{tabular}{|c|c|c|c|c|}
\hline \multicolumn{2}{|c|}{ Vocational Identity } & $\begin{array}{c}\text { Affective } \\
\text { Commitment }\end{array}$ & $\begin{array}{c}\text { Continuance } \\
\text { Commitment }\end{array}$ & $\begin{array}{c}\text { Normative } \\
\text { Commitment }\end{array}$ \\
\hline \multirow{3}{*}{$\begin{array}{c}\text { Religious } \\
\text { Brother }\end{array}$} & Mean & 24.3704 & 18.1111 & 22.2593 \\
\cline { 2 - 5 } & $\mathrm{N}$ & 27 & 27 & 27 \\
\cline { 2 - 5 } & $\begin{array}{c}\text { Std. } \\
\text { Deviation }\end{array}$ & 3.36439 & 4.24566 & 3.41482 \\
\hline
\end{tabular}




\begin{tabular}{|c|c|c|c|c|}
\hline \multirow{4}{*}{$\begin{array}{c}\text { Diocesan } \\
\text { Priest }\end{array}$} & Mean & 25.6667 & 19.6667 & 23.7778 \\
\cline { 2 - 5 } & $\mathrm{N}$ & 9 & 9 & 9 \\
\cline { 2 - 5 } & $\begin{array}{c}\text { Std. } \\
\text { Deviation }\end{array}$ & 3.39116 & 4.27200 & 4.32371 \\
\hline \multirow{4}{*}{$\begin{array}{c}\text { Religious } \\
\text { Sister }\end{array}$} & Mean & 24.8588 & 16.9412 & 23.0118 \\
\cline { 2 - 5 } & $\mathrm{N}$ & 85 & 85 & 85 \\
\cline { 2 - 5 } & $\begin{array}{c}\text { Std. } \\
\text { Deviation }\end{array}$ & 3.38819 & 4.81899 & 3.95358 \\
\hline \multirow{4}{*}{$\begin{array}{c}\text { Religious } \\
\text { Priest }\end{array}$} & Mean & 23.9000 & 19.8000 & 23.6000 \\
\cline { 2 - 5 } & $\mathrm{N}$ & 10 & 10 & 10 \\
\cline { 2 - 5 } & $\begin{array}{c}\text { Std. } \\
\text { Deviation }\end{array}$ & 3.63471 & 4.96208 & 3.06232 \\
\hline \multirow{4}{*}{ Total } & Mean & 24.7405 & 17.5878 & 22.9542 \\
\cline { 2 - 5 } & $\mathrm{N}$ & 131 & 131 & 131 \\
\cline { 2 - 5 } & $\begin{array}{c}\text { Std. } \\
\text { Deviation }\end{array}$ & 3.38455 & 4.73753 & 3.79648 \\
\hline
\end{tabular}

Source: SPSS Output (2021)

Table 7 shows that respondents who were diocesan priests had highest mean in affective commitment (mean=25.6667) as well as highest mean in normative commitment (mean=23.7778). With respect to continuance commitment, religious priests had highest mean (mean=19.8000). On the other hand, respondents who were religious priests had lowest mean of affective commitment (mean=23.9000) while respondents who were religious brothers had lowest mean for continuance commitment and normative commitment (mean=18.1111) and (mean=22.2593) respectively.

The diocesan priests scoring high in affective commitment and continuance commitment can be attributed to for being the native of Lodwar diocese. This means that they are familiar with the place. Scoring high on normative commitment can be attributed to expected moral obligation to make their diocese a better place to live.

\section{DISCUSSION}

Other Scholars have studied organizational commitment with varying findings. For instance a study by Donna (2015) to investigate job satisfaction and its relationship to organizational and religious commitment among 263 workers at northern Caribbean university found that there was no significant difference in organizational commitment among the educational level of Northern Caribbean University workers.

Candelario, Tindowen, Mendezabal and Quilang (2020) conducted a study to investigate Organizational Commitment and Job Satisfaction among Government Employees. The respondents of this study were the 50 employees of a government agency in the Northern Philippines. Organizational commitment was measured using the Organizational Commitment Questionnaire developed and modified by Meyer and Allen (2006).The organizational commitment was computed in terms of means where the lowest possible ean was 1 and the highest possible mean was
5. The study findings revealed that the organizational commitment of the respondents was generally high (mean= 3.80). With respect to specific subscales the level of affective organizational commitment was the highest (mean= 3.98), followed by and normative organizational commitment $($ mean $=3.76)$. The continuance organizational commitment level was the lowest $($ mean $=3.76)$ among the subscales but was above average.

Sarisik, Bogan, Zengin and Dedeoglu (2019) carried out a study to investigates the relationship between burnout and organizational commitment. The sample included 700 public officers in Istanbul Turkey. Data was collected using questionnaires.The partial least squares method (PLS-SEM) was used to test the hypothesesThe study findings revealed that employees' burnout was negatively related to organizational commitment. Specifically, the emotional exhaustion was found to be negatively related to commitment, while personal accomplishment on the other hand was found to be positively related to commitment. However, the experience of depersonalization had no significant relationship with all three dimensions of commitment.

Yin (2017) carried out a study to explore the relationship between job engagement and job burnout, job engagement and job performance. 633 respondents who were employees of 48 companies randomly chosen took part in the study. Data was collected by use of questionnaires. The study findings revealed that Job engagement negatively affects job burnout.

Conducted a study to assess the levels of work engagement in organizations located in Mexico City using standardized tests, and to determine its relationship with the occurrence of occupational burnout (OB), organizational socialization (OS), and psychological resilience. A sample of 1110 employees was recruited to participate in the study. Utrecht Work Engagement Scale, the Organizational Socialization Inventory, the Occupational Burnout Scale, and the Mexican Resilience Scale were used to measure the variables. The study results revealed that work engagement casually decreased the probability of developing OB.

Ahuja and Gupta (2018) carried out cross-sectional descriptive study to investigate Organizational Commitment and Work Engagement as a Facilitator for Sustaining Higher Education Professionals. Work Engagement Scale developed by Schaufeli et al. (2006) and organizational Commitment scale developed by Saks (2006) were used. Data was analyzed using hierarchical multivariate analysis. The study findings revealed that there was a strong correlation between organizational commitment and work engagement $(\mathrm{r}=.539, \mathrm{p}$ $<.05)$.

Stephen (2013) carried out a study to determine the influence of job satisfaction, organizational commitment, and employee engagement on intent to leave among 244 public school teachers in south Louisiana. Data collection instruments included; Job Descriptive Index/Job In General, the Organizational Commitment Questionnaire, the Utrecht Work 
and Well Being Survey, three-point Intent to Leave instrument, and a demographic survey. Each of the engagement scale/subscale scores derived from this study were examined, and the following results were found. For the "Vigor subscale, the largest group $(n=97,39.8 \%)$ of respondents were found to be at the "Average" level of engagement compared to the normative sample. Similarly, almost half of respondents $(n=116,47.5 \%)$ were found to be at the "High" or greater level of engagement. For the "Dedication" subscale, the largest group of respondents $(\mathrm{n}=$ $119,48.6 \%$ ) were found to be at the "High" level of engagement compared to the normative sample. Over two thirds $(n=171,69.8 \%)$ of the respondents were found to be at the "High" or greater level of engagement. Lastly, for the "Absorption" subscale, the largest group $(\mathrm{n}=113,46.1 \%)$ were found to be at the "High" level of engagement compared to the normative sample. Over three quarters $(n=205,83.7 \%)$ of the respondents were found to be at the "High" or greater level of engagement. Overall, the largest group $(n=102$, $41.6 \%$ ) of respondents were found to be at the "High" level of engagement. Almost two-thirds $(n=157,64.0 \%)$ were found to be at the "High" or greater level of engagement.

Ahmed and Dajani (2015) conducted an exploratory study on The Impact of Employee Engagement on Job Performance and Organizational Commitment in the Egyptian Banking Sector. 245 banking employees from several private and public banks operating in Cairo-Egypt took part in the study. Data was collected using a survey questionnaire. To get the relationship between variables under study, regression analysis and Pearson correlation analysis were used. The study findings revealed that Employee engagement had significant impact on job performance, but less impact on organizational commitment.

Adewale (2020) used survey research design to investigate influence of work engagement on job burnout among librarians in university libraries in Nigeria. The sample size comprised of 624 librarians from all the 38 public universities (Federal and State) in Southern Nigeria. Data were analyzed using descriptive and inferential statistics. The study findings revealed that work engagement $(\beta=.184, \mathrm{t}(498)=4.191, \mathrm{R} 2$ $=.034, \mathrm{p}<.05$ ) significantly influenced job burnout of librarians in university libraries in Nigeria. The study concluded that work engagement contribute to low level of job burnout among librarians in universities in Nigeria and library management should maintain good work practice to prevent job burnout.

Rameshkumar (2020) carried out a survey study on Employee engagement as an antecedent of organizational commitment using Indian seafaring officers. The sample size for the study included 440 respondents. Data was collected using questionnaire which had demographic details of respondents, questions on engagement and organizational commitment. This study found that employee engagement was positively associated with affective and normative components of organization commitment. On the other hand, the study findings on the relationship between employee engagement and continuance component of organizational commitment was found not to be significantly associated

Prerana (2017) conducted a study to find out the effect of employees engagement on organizational commitment in an Indian public sector organization. Sample size comprised of 30 employees from a leading public sector bank. Data was collected using questionnaire. The study findings revealed that employee engagement (Job Satisfaction and Job Involvement) had significant correlation with the organizational commitment.

\section{CONCLUSION}

The findings of this study have revealed that the demographic characteristics of age, gender, educational level, country of origin and vocation identity has influence on organizational commitment among the Catholic religious men and women working in rural areas. Based on these findings, the industrial psychologists can be aware of the influence of demographic characteristics to organizational commitment. When industrial psychologists are participating in recruiting employees in the organization, they need to be aware that demographic characteristics have an influence on organizational commitment of employees. Also the findings of this study can help industrial psychologists to factor the influence of demographic characters on organizational commitment when they carrying out performance appraisals. The counselors and psychologists employed in organizations to offer counseling services to employees can utilize knowledge of these findings in understanding commitment of employees. Though this study was focused on the commitment of catholic religious men and women working in rural areas, it can as well applied to employees working in secular organizations.

\section{REFERENCE}

[1] Adewale, A. A. (2020). "Influence of Work Engagement on Job Burnout among Librarians in University Libraries In Nigeria". Library Philosophy and Practice (e-journal). 4017.

[2] Ahmed, M. \&Dajani, Z. (2015). "The Impact of Employee Engagement on Job Performance and Organisational Commitment in the Egyptian Banking Sector." Journal of Business and Management Sciences, 3 (5): 138-147

[3] Ahuja, S. \& Gupta, S. (2018). Organizational Commitment and Work Engagement as a Facilitator for Sustaining Higher Education Professionals. International Journal of Recent Technology and Engineering (IJRTE), 7 (6); 1846-1851

[4] Allen, N.J., \& Meyer, J.P. (1990). The Measurement and Antecedents of Affective, Continuance, and Normative Commitment to the Organization. Journal of Occupational Psychology, 63, 1-18.

[5] Candelario, Lorena \&Tindowen, Darin Jan \&Mendezabal, Marie \&Quilang, Pyrene. (2020). Organisational Commitment and Job Satisfaction among Government Employees. International Journal of Innovation, Creativity and Change, 13 (10); 1627-1643.

[6] Creswell, J. W., \& Creswell, J. D. (2017). Research design: Qualitative, quantitative, and mixed methods approaches. Sage publications.

[7] Creswell, J. W., Plano Clark, V. L., Gutmann, M., \& Hanson, W. (2003). Advanced mixed methods research designs. In A. Tashakkori\& C. Teddlie (Eds.), Handbook ofmixed methods in 
social and behavioral research (pp. 209-240). Thousand Oaks, CA: Sage.

[8] Donna, B. (2015). "Job Satisfaction and its Relationship to Organizational and Religious Commitment Among Workers at Northern Caribbean University". Dissertations. 243

[9] Gbadamosi, G. (2006). Predictors and Correlates of Charlatan Behavior in a Non-Western Consent. Journal of Global Business and Technology, 2, 23-32.

[10] Hogan, N.L., Lambert, E.G., \& Griffin, M.L. (2013). Loyalty, love, and investments: The impact of job outcomes on the organizational commitment of correctional staff. Criminal Justice and Behavior, 40, 355-375

[11] Jaros, S.J., Jermier, J.M., Koehler, J.W., \&Sincich, T. (1993). Effects of Continuance, Affective, And Moral Commitment on the Withdrawal Process: An Evaluation of Eight Structural Equation Models. The Academy of Management Journal, 36, 951-995.

[12] Lambert, E.G., Hogan, N.L., Paoline, E.A., \& Stevenson, M.T. (2008). I Want To Know And I Want to Be Part of It: The Impact of Instrumental Communication and Integration on Private Prison Staff. Journal of Applied Security Research, 3, 205-229.

[13] McLeod, S. A. (2019). Sampling methods. Simply Psychology. htt ps://www.simplyps ychology.org/sampling.html

[14] Meyer, J.P., \& Allen, N.J. (1984). Testing the "side-bet theory" of organizational commitment: Some methodological considerations. Journal of Applied Psychology, 69, 372-378

[15] Meyer, J.P., \&Herscovitch, L. (2001). Commitment in the Workplace: Toward A General Model. Human Resource Management Review, 11, 299-326.

[16] Mowday, R.T. (1998). Reflections on the study and relevance on organizational commitment. Human Resource Management, 8, $387-401$
[17] Orodho, A.J., \& Kombo, D. K. (2002). Research Methods. Nairobi: Kenyatta University, Institute of Open Learning.

[18] Orodho. (2003). Essentials of Educational and Social Sciences Research Method. Nairobi: Masola Publishers.

[19] Penley, L.E., \& Gould, S. (1998). Etzioni's model of organizational involvement: A perspective for understanding commitment to organizations. Journal of Organizational Behavior, 9, 43-59.

[20] Prerana, (2017). "Effect of Employee Engagement on Organizational Commitment," Indian Journal of Commerce and Management Studies, Educational Research Multimedia \& Publications,India, vol. 8(2), pages 101-108.

[21] Rameshkumar, M. (2020). Employee engagement as an antecedent of organizational commitment - A study on Indian seafaring officers. The Asian Journal of Shipping and Logistics, 36 (3); 105112 ,

[22] Sarisik, M., Bogan, E., Zengin, B., \&Dedeoglu, B. B. (2019). The impact of burnout on organizational commitment: A study of public sector employees in Turkey. Journal of Global Business Insights, 4(2), 106-118

[23] Stephen, B. T. (2013). "The influence of job satisfaction, organizational commitment, and employee engagement on intent to leave among public school teachers in south Louisiana". LSU Doctoral Dissertations. 1311

[24] Wiener, Y. (1982). Commitment in Organizations: A Normative View. Academy of Management Review, 7, 418-428.

[25] Yin, N. (2017). The Effect of Job Engagement on Job Burnout and Job Performance: The Moderating Effect of Organizational Justice. International Journal of Business and Management, 12 (5); $1-15$ 